\title{
KARAKTERISASI DAN EVALUASI POPULASI ABALON Haliotis squamata SECARA MOLEKULER, MORFOMETRIK, DAN BIOLOGI
}

\author{
Gusti Ngurah Permana*)*, Rudhy Gustiano*), Ibnu Rusdi*), Fitriyah Husnul Khotimah*), \\ Bambang Susanto*), dan Dedi Duryadi Solihin**) \\ *) Balai Besar Riset Budidaya Laut dan Penyuluhan Perikanan \\ **) Fakultas Matematika dan IImu Pengetahuan Alam, Departemen Biologi, Institut Pertanian Bogor
}

(Naskah diterima: 25 Juli 2017; Revisi final: 3 Oktober 2017; Disetujui publikasi: 3 Oktober 2017)

\begin{abstract}
ABSTRAK
Abalon merupakan salah satu komoditas penting gastropoda laut. Tingginya permintaan abalon ini mengakibatkan menipisnya stok di alam. Oleh karena itu, upaya keberhasilan budidaya abalon perlu didukung oleh jenis unggul. Indikasi awal suatu jenis unggul dapat dilakukan dengan menganalisis potensi genetik yang dimiliki. Penelitian ini dilakukan dengan analisis gen 165 rRNA, karakter morfolologi, dan biologi dianalisis secara deskriptif dengan metode kajian pustaka. Hasil yang diperoleh menunjukkan keragaman inter populasi Haliotis squamata mendeteksi adanya tujuh haplotipe yang terbagi dalam dua kelompok. Penyertaan $\mathrm{H}$. diversicolor sebagai outgroup dalam pengujian memperlihatkan bahwa populasi $\mathrm{H}$. squamata dari Pulau Bali dan beberapa lokasi di Pulau Jawa berada dalam satu kelompok yang terpisah dengan outgroup. Hasil ini kongruen dengan analisis morfometrik terdapat perkembangan pertumbuhan cangkang yang asimetri pada populasi Banten. Pertumbuhan asimetri merupakan indikasi spesifik untuk populasi Banten atau merupakan gejala abnormalitas yang dapat diakibatkan oleh faktor penurunan kualitas genetik atau lingkungan. Karakter biologi terlihat proporsi daging dan gonad berbeda pada populasi Banten dengan indikasi adanya pertumbuhan asimetri. Rasio gonad dan daging populasi Banyuwangi berbeda nyata $(P<0,05)$ dengan populasi lainnya.
\end{abstract}

KATA KUNCl: abalon; biologi; Haliotis squamata; morfometrik; mitokondria; dan sgenetik; 16Sr RNA

ABSTRACT: Morphometrical, biological, and molecular evaluation and characterization of abalone Haliotis squamata. By: Gusti Ngurah Permana, Rudhy Gustiano, Ibnu Rusdi, Fitriyah Husnul Khotimah, Bambang Susanto, and Dedi Duryadi Solihin

\begin{abstract}
Abalone is arguably one of the highly valued and sought-after marine gastropods. However, the over-exploitation of this species has exhausted its wild stock. To overcome this challenge, the culture technique and management of this species must be established and continually improved. One of the ways is through producing superior broodstocks. An initial assessment of a genetically superior broodstock can be done using the potential genetic analysis. This recent research employed the analysis to study the species' $16 \mathrm{~S}$ rRNA gene. To complement the study, the morphometric and biological characteristics of the species were analyzed descriptively with the aid of scientific literature. The results showed that the interpopulation diversity of Haliotis squamata was detected by the presence of seven haplotypes divided into two groups. The inclusion of $\mathbf{H}$. diversicolor as an outgroup within the test showed that the populations of abalone in Bali and several other sites in Java were genetically separated from the outgroup. This finding can be backed up with the result of the morphometric analysis where there was asymmetric shell growth in Banten abalone population. This asymmetric growth is considered as a symptom of abnormality caused by genetic or environmental degradation factors. The biological characteristics showed the different ratios of meat and gonad in the Banten population due to the asymmetric growth. Banyuwangi population was significantly different $(P<0.05)$ from other populations in terms of meat and gonad ratios.
\end{abstract}

KEYWORDS: abalon; biology; Haliotis squamata; morphometric; mitochondria and genetic; 16Sr RNA

\footnotetext{
\# Korespondensi: Balai Besar Riset Budidaya Laut dan

Penyuluhan Perikanan. JI. Br. Gondol Kec. Gerokgak Kab.

Buleleng, Po. Box 140, Singaraja 81155, Bali, Indonesia.

Tel. + (0362) 92278

E-mail: gustipermana@ gmail.com
} 


\section{PENDAHULUAN}

Abalon merupakan jenis moluska yang hidup di perairan Indonesia. Secara umum, abalon memiliki habitat pantai yang berkarang, di Indonesia Timur (Ambon dan Sulawesi), Indonesia Tengah (Lombok dan Bali), dan Pesisir Selatan Pulau Jawa. Abalon dengan ukuran cangkang di atas $9 \mathrm{~cm}$ ditemukan di perairan Sumba dan Timor, sedangkan untuk spesies $\mathrm{H}$. squamata dilaporkan banyak ditemukan di perairan Selatan Bali dan Jawa (Priyambo do et al., 2005; Dharma, 2008).

Selama ini sebaran spasial Haliotis squamata di perairan Indonesia belum banyak diungkapkan, secara komprehensif dan holistik dari berbagai aspek dan pendekatan keilmuan. Kajian genetika populasi akan menyediakan data dasar populasi terkait dengan potensi genetik dan biologi. Oleh karena itu, informasi yang diperoleh yang ada di Indonesia sangat penting dilakukan untuk menentukan arah strategi kebijakan yang dapat diambil bagi pengembangan budidaya abalon yang kompetitif dan berdaya saing. Sementara itu, penentuan karakter jenis secara biometrik meskipun terkadang dianggap klasik tetap merupakan cara yang cukup akurat untuk membedakan karakter banyak spesies.

Dewasa ini, analisis keragaman genetik menggunakan material genetik berasal dari DNA inti maupun dari DNA mitokondria. Marka DNA mitokondria terutama 16S rRNA dan Cytochrome C Oxidasesubunit-I (COI) digunakan untuk menganalisis keragaman genetik jenis abalon di pantai Korea dapat membedakan spesies yang menjadi dasar penentuan strategi budidaya abalon di negara tersebut (An et al., 2005). Karakter unik dari polimorfisme sekuen DNA mitokondria dapat memberikan resolusi informasi yang tinggi mengenai evolusi hubungan antara anggota taxon yang sama maupun dengan taxon berbeda di tingkat spesies, famili maupun tingkatan yang lebih tinggi seperti ordo dan seterusnya. Hal itu disebabkan oleh laju evolusi dari material genetik DNA mitokondria 10 kali lebih cepat dibandingkan yang terjadi pada DNA inti (Brown et al., 1979; Klinbunga et al., 2003).

Gen 16S rRNA merupakan salah satu gen ribosomal berukuran besar pada genom mitokondria yang bersifat konservatif sehingga sangat cocok memilah spesies dan hubungan kekerabatan lainnya. Ukuran gen ini sekitar 1.500 hingga 1.600 pasang basa (Klinbunga et al., 2003). Gen 16S rRNA tidak seluruh sekuennya digunakan sebagai marka genetik, akan tetapi hanya bagian tertentu (partial) saja yaitu sekitar 500-700 pasang basa (Klinbunga et al., 2003). Penelitian ini bertujuan untuk mengevaluasi keragaman genetik berdasarkan polimorfisme nukleotida gen 16S rRNA, dan karakter morfometrik, serta analisis biologi abalon dari populasi alami abalon jenis H. squamata di Pulau Jawa dan Bali dengan sebaran spasial berbeda.

\section{BAHAN DAN METODE}

Abalon H. squamata dikoleksi sebanyak 150 ekor dalam keadaan hidup dari setiap lokasi yang diamati. Abalon diperoleh dari perairan Negara (Provinsi Bali), Banyuwangi (Provinsi Jawa Timur), Pangandaran (Provinsi Jawa Barat), dan Binuangen (Provinsi Banten) (Gambar 1). Pengamatan molekuler dilakukan menggunakan jaringan lunak, sedangkan untuk morfometrik dan biologis dilakukan terhadap cangkang, daging, dan gonad.

\section{Analisis 165 rRNA}

Sebanyak 20 ekor sampel dari setiap lokasi digunakan untuk analisis DNA. Sampel yang dipergunakan adalah dari bagian epipodium yang diawetkan dalam alkohol absolut.

\section{Prosedur Analisis}

\section{Ekstraksi dan Purifikasi DNA}

DNA genomik diekstrak dari epipodium sampel abalon (500 mg) menggunakan DNeasy Blood \& Tissue $^{T M}$ (QIAGEN, Hilden, Germany) sesuai dengan petunjuk perusahaan. Purifikasi dilakukan dengan menggunakan spin kolom yang tersedia dalam kit ekstraksi tersebut. DNA genomik yang dihasilkan dimigrasikan dalam gel agarose dengan teknik elektroforesis. DNA yang dihasilkan menjadi DNA template untuk proses amplifikasi gen 16S rRNA.

\section{Amplifikasi Gen 165 rRNA}

Amplifikasi gen 16S rRNA dilakukan dengan menggunakan mesin PCR dengan primer forward $A B$ 16S-F: 5'-CGCCTGTTTATCAAAAACAT-3' dan reverse AB-16S-R: 5'-CTCCGGTTTGAACTCAGATC-3'. Komponen reaksi terdiri atas: $5 \mu \mathrm{L}$ template DNA; $1 \mu \mathrm{L}$ primer forward (AB-16S-F); dan $1 \mu \mathrm{L}$ primer reverse (AB-16S-R) dengan konsentrasi $20 \mathrm{\rho mol} / \mu \mathrm{L} ; 5 \mu \mathrm{L}$ buffer reaction Q5, $5 \mu \mathrm{L}$ enhancer Q5; $1 \mu \mathrm{L}$ dNTP mix; 0,2 $\mu \mathrm{L}$ Taq Hotstar high fidality; dan $6,8 \mu \mathrm{L}$ nuclease free water; sehingga total reaksi adalah $25 \mu \mathrm{L}$. Proses PCR dilakukan dengan tahapan reaksi sebagai berikut: sampel didenaturasi pada suhu $94^{\circ} \mathrm{C}$ selama 4,5 detik; dilanjutkan annealing pada suhu $46^{\circ} \mathrm{C}$ selama 60 detik, dan extension pada suhu $72^{\circ} \mathrm{C}$ selama 60 detik sebanyak 35 siklus. Setelah itu, proses PCR dilanjutkan dengan post extension pada suhu $72^{\circ} \mathrm{C}$ selama tujuh menit, dan diakhiri pada suhu 


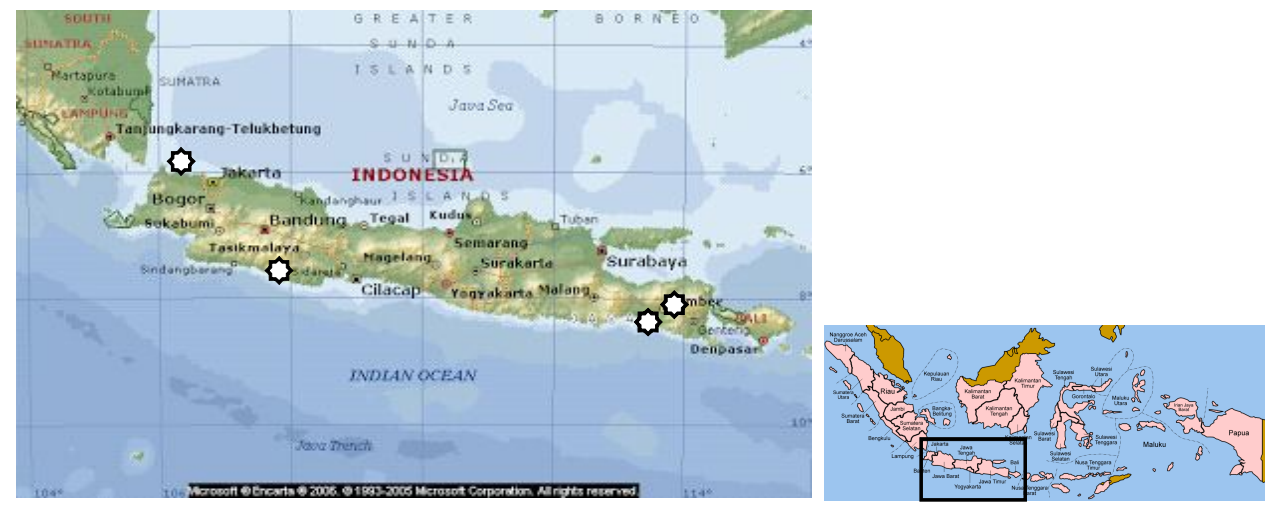

Keterangan (Remarks): Lokasi pengambilan sampel (Sampling site)

Gambar 1. Lokasi pengambilan sampel abalon (H. squamata).

Figure 1. Sampling locations of abalone (H. squamata).

$20^{\circ} \mathrm{C}$ selama 15 menit. Untuk mengetahui apakah proses PCR berjalan baik, maka produk PCR-nya dimigrasikan dalam piranti elektroforesis submarine menggunakan gel agarose $1,2 \%$

\section{Sekuensi Produk PCR}

Produk PCR dipurifikasi, kemudian dilanjutkan dengan proses sekuensi. Sekuensi produk PCR menggunakan metode Big Dye Terminatioan dengan Genetic Analyzer 3730XL (Applied Biosystems) dilakukan di perusahaan First Base Singapura melalui perusahaan jasa sekuensi di Indonesia yaitu PT Genetika Science, Jakarta.

\section{Analisis Genetik}

Data sekuens diolah dengan menggunakan Sequence Scaner version 1.0 dari Applied Biosystem (AB) 2005. Pensejajaran hasil sequens baik berdasarkan primer forward maupun primer reverse dilakukan dengan memakai program MEGA (Molecular Evolutionary Genetic Analysis) versi 5 (Tomura et al., 2011). Jarak genetik dianalisis berdasarkan p-distance, sedangkan rekonstruksi pohon filogenetik dengan Neibour joining memakai bootstraps sebanyak 1.000 pengulangan (Tomura et al., 2011). Sebagai pembanding dipakai data sekuens 16S rRNA abalon jenis Haliotis diversicolor diversicolor dengan code access gene bank: AY146397 (An et al., 2005).

\section{Analisis Morfometrik}

Abalon pada masing-masing populasi dipilih 30 ekor dan dilakukan pengukuran morfometrik dengan cara menghubungkan jarak antar diagonal dari abalon tersebut (Gambar 2).

\section{Analisis Biologi}

Pengamatan biologi abalon dilakukan mengukur panjang cangkang dan bobot abalon. Tahap selanjutnya yaitu memisahkan cangkang, daging, dan gonad. Masing-masing sampel yang sudah dipisahkan kemudian diukur bobotnya. Jumlah abalon yang diukur sebanyak 30 ekor dari masing-masing daerah pengamatan. Analisis data meliputi rasio gonad terhadap tubuh dan rasio daging terhadap berat total.

\section{HASIL DAN BAHASAN}

\section{Komposisi Genetik dan Frekuensi Haplotipe}

\section{Hasil amplifikasi gen 16S rRNA secara partial}

Berdasarkan hasil amplifikasi DNA abalon dengan primer spesifik untuk 16S rRNA didapatkan hasil amplifikasi sebesar 573 pasang basa (Gambar 3).

\section{Keragaman Sekuens Nukleotida}

Hasil pensejajaran sekuensi nukleotida parsial 165 rRNA interpopulasi sesama jenis $H$. squamata dari delapan sampel didapatkan tujuh haplotipe dengan jarak genetik intra-individu populasi BL (Bali) $=0,002$ 0,003 atau $0,2 \% 0,3 \%$ dengan rata-rata $0,23 \%$ Perbedaan intra-individu populasi BTN (Banten)= 0,002-0,003 atau 0,2\%0,3\% dengan rata-rata $0,21 \%$ Perbedaan intra-individu populasi BW (Banyuwangi)= 0,007-0,010 atau $0,7 \% 1,0 \%$ dengan rata-rata $0,85 \%$ Perbedaan intra-individu populasi PN (Pangandaran)= $0,002-0,009$ atau $0,2 \% 0,9 \%$ dengan rata-rata $0,25 \%$ Nilai polimorfisme enzymes dengan analisis allozyme menurut Fakhruddin et al. (2010), abalon asal Banten dan Bali lebih tinggi jika dibandingkan dengan analisis allozyme abalon banten $(0,13)$ dan Bali $(0,06)$. Populasi 


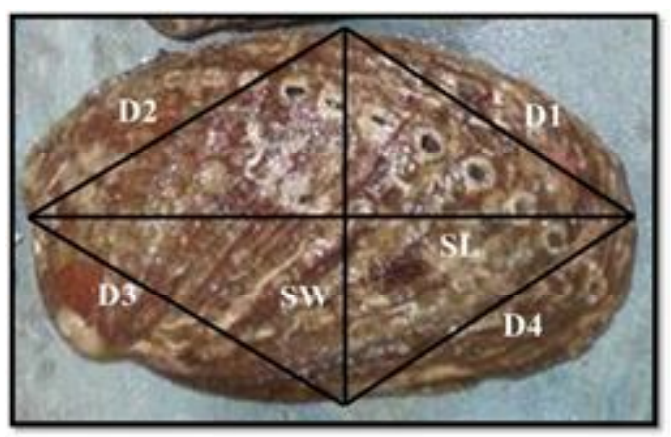

Keterangan: SL: jarak antara titik tengah ujung cangkang dan lubang respirasi pertama (jarak terpanjang cangkang); SW: jarak antara bagian atas cangkang dan bagian bawah cangkang (jarak terlebar cangkang); D1: jarak diagonal antara titik pangkal lubang respirasi pertama dan titik lebar cangkang bagian atas; D2: jarak diagonal antara titik lebar cangkang bagian atas dan titik tengah ujung cangkang; D3: jarak diagonal antara titik tengah ujung cangkang dan titik lebar cangkang bagian bawah; D4: jarak diagonal antara titik lebar cangkang bagian bawah dan titik pangkal lubang respirasi (Soelistyowati et al., 2013)

Remarks: SL: the distance between the tip of the shell and the first respiration hole (the longest distance of the shell), SW : the distance between the top of the shell and the bottom of the shell (the widest distance of the shell), D1: the diagonal distance between the starting point of the first respiratory hole and the upper shell's width point, D2: the diagonal distance between the width of the upper shell and the midpoint of the tip, D3: the diagonal distance between the center width of the tip of shell and the point of lower shell's width, D4: diagonal distance between the width of the bottom shell and the base of the respiratory hole (Soelistyowati et al., 2013)

Gambar 2. Karakter morfometrik Haliotis squamata.

Figure 2. Truss morfometric of Haliotis squamata.

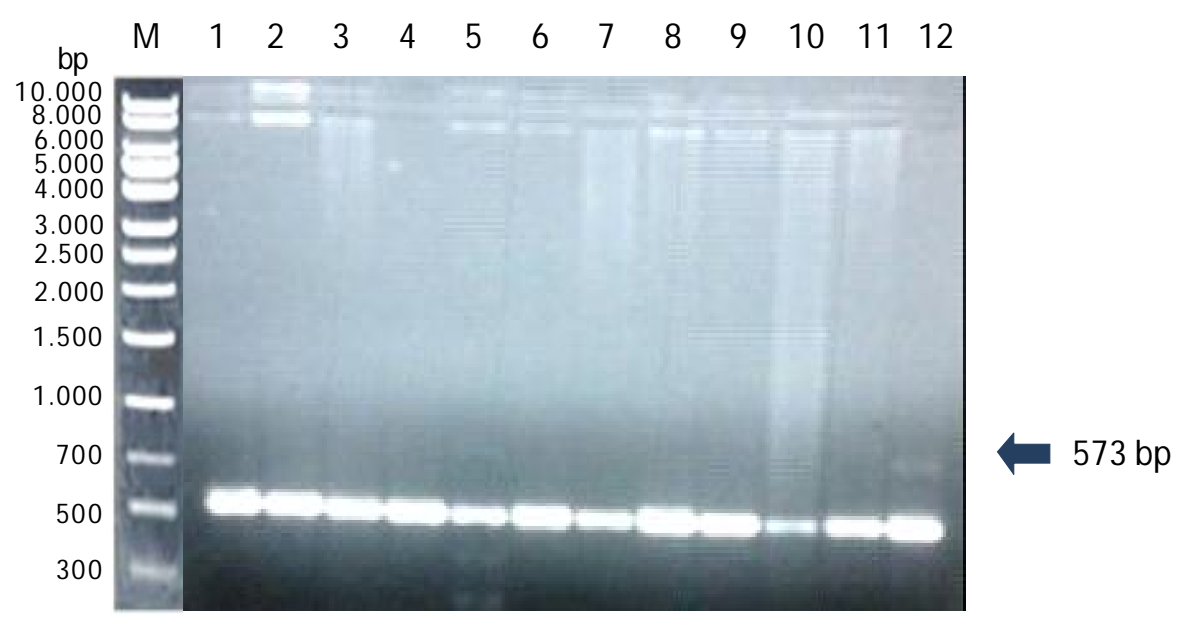

Gambar 3. Hasil amplifikasi gen $16 \mathrm{~S}$ rRNA parsial pada abalon. Tanda panah menunjukkan fragmen DNA; $M=$ marker DNA $1 \mathrm{~kb} ; 1-12=$ fragmen DNA hasil PCR.

Figure 3. DNA amplification of 165 rRNA partial gene of abalone. Arrow indicated the fragment of DNA; $M=$ marker DNA $1 \mathrm{~kb} ; 1-12=$ DNA fragment of PCR product. 
dengan poliorfisme yang tinggi disinyalir akan memiliki peluang hidup yang semakin tinggi untuk beradaptasi dengan perubahan lingkungan.

Hasil pensejajaran sekuens nukleotida parsial $16 \mathrm{~S}$ rRNA interpopulasi sesama jenis $\mathrm{H}$. squamata setelah ditambahkan pembanding out-group, yaitu $\mathrm{H}$. diversicolor diversicolor, maka dari delapan sampel yang telah dianalisis didapatkan delapan haplotipe dari populasi $\mathrm{H}$. squamata dengan jarak perbedaan intraindividu populasi $\mathrm{BL}=0,002-0,004$ atau $0,2 \% 0,4 \%$ dengan rata-rata 0,0027 atau $0,27 \%$ Perbedaan intraindividu populasi BTN $=0,002-0,004$ atau $0,2 \% 0,4 \%$ dengan rata-rata 0,0027 atau $0,27 \%$ Perbedaan intraindividu populasi BW (Banyuwangi) $=0,007-0,011$ atau $0,7 \% 1,1 \%$ dengan rata-rata $0,86 \%$ Perbedaan intraindividu populasi PN (Pangandaran) $=0,002-0,009$ atau $0,2 \% 0,9 \%$ dengan rata-rata $0,27 \%$ Perbedaan antara populasi $H$. squamata dengan $H$. diversicolor diversicolor $=0,050-0,0,57$ atau 5,0\%5,7\%dengan ratarata 0,052 atau $5,2 \%($ Tabel 1$)$.

\section{Hubungan Kekerabatan}

Pengelompokan individu interpopulasi $H$. squamata menghasilkan dua kelompok, yaitu kelompok pertama terdiri atas individu BL-6, BTN-7, BTN-1, PN-1, BTN-2, BL-2, dan BL-7; Kelompok kedua terdiri atas individu BW-7. Hubungan kekerabatan antara kelompok-1 dan kelompok-2 adalah 0,0086 atau $0,86 \%$ Pada kelompok pertama terbagi lagi menjadi dua sub-kelompok (I-a) yaitu yang terdiri atas BL-6, BTN-7, BTN-1, PN-1, BTN-2; sub kelompok (I-b) terdiri atas BL-2 dan BL-7, dengan perbedaan dua sub kelompok tersebut sebesar 0,0027 atau sebesar 0,27\% (Gambar 4).
Penambahan out-group dengan $\mathrm{H}$. diversicolor diversicolor terlihat pohon filogeni hubungan kekerabatannya terbagi dua kelompok, yaitu kelompok pertama terdiri semua individu dari H. squamata, sedangkan kelompok kedua hanya berisi H. diversicolor diversicolor (Gambar 5). Hubungan kekerabatan antara kelompok-1 dan kelompok-2 adalah 0,052 atau $5,2 \%$

\section{Karakter Morfologi Abalon H. squamata}

Keragaan morfologi abalon $\mathrm{H}$. squamata yang diambil dari keempat lokasi diidentifikasi secara morfologi seperti terlihat pada Tabel 2 .

Berdasarkan Tabel 2 terlihat bahwa parameter D3 dan D4 tidak terdapat perbedaan pada empat populasi $(P>0,05)$, namun pada D1 (jarak diagonal antara titik pangkal lubang respirasi pertama dan titik lebar cangkang bagian atas) dan D2 (jarak diagonal antara titik lebar cangkang bagian atas dan titik tengah ujung cangkang) pada populasi Banyuwangi, Pangandaran, dan Bali berbeda dengan populasi Banten. Hal ini mengindikasikan bahwa terdapat perkembangan pertumbuhan cangkang yang asimetri pada populasi Banten. Pertumbuhan asimetri merupakan indikasi spesifik untuk populasi Banten atau merupakan gejala abnormalitas yang dapat diakibatkan oleh faktor penurunan kualitas genetik atau lingkungan yang patut dikaji lebih lanjut. Menurut Møller \& Swaddle (2002), asimetri berhubungan erat dengan evolusi, biologi, dan lingkungan. Faktor lingkungan, yang memengaruhi ketersediaan pangan terhadap perbedaan pertumbuhan dan morfologi (Saunders et al., 2009). Asimetri merupakan signal awal tentang kualitas reproduksi, serta hal yang perlu dikaji adalah faktor ekologi,

Tabel 1. Matriks perbedaan antar individu dan populasi spasial berbeda dari H. squamata dengan out-grup $\mathrm{H}$. diversicolor diversicolor berdasarkan sekuens gen 16S rRNA

Table 1. The matrix showing the difference between individual and spatial populations is different from $\mathbf{H}$. squamata with the outgroup $\mathbf{H}$. diversicolor diversicolor based on 165 rRNA gene squences

\begin{tabular}{lccccccccc}
\hline Individual & BL-2 & BL-6 & BL-7 & BTN-1 & BTN-2 & BTN-7 & BW-7 & PN-1 & H. div \\
\hline BL-2 & & & & & & & & & \\
BL-6 & 0.002 & & & & & & & & \\
BL-7 & 0.002 & 0.004 & & & & & & & \\
BTN-1 & 0.002 & 0 & 0.004 & & & & & & \\
BTN-2 & 0 & 0.002 & 0.002 & 0.002 & & & & & \\
BTN-7 & 0.004 & 0.002 & 0.005 & 0.002 & 0.004 & & & & \\
BW-7 & 0.007 & 0.009 & 0.009 & 0.009 & 0.007 & 0.011 & & & \\
PN-1 & 0.002 & 0 & 0.004 & 0 & 0.002 & 0.002 & 0.009 & & \\
Hd_div & 0.052 & 0.050 & 0.054 & 0.050 & 0.052 & 0.052 & 0.057 & 0.050 & \\
\hline
\end{tabular}

Keterangan: $\mathrm{BL}=$ Bali, $\mathrm{BTN}=$ Banten, $\mathrm{BW}=$ Banyuwangi, dan $\mathrm{PN}=$ Pangandaran

Remarks: $\mathrm{BL}=$ Bali, $\mathrm{BTN}=$ Banten, $\mathrm{BW}=$ Banyuwangi, and $\mathrm{PN}=$ Pangandaran 

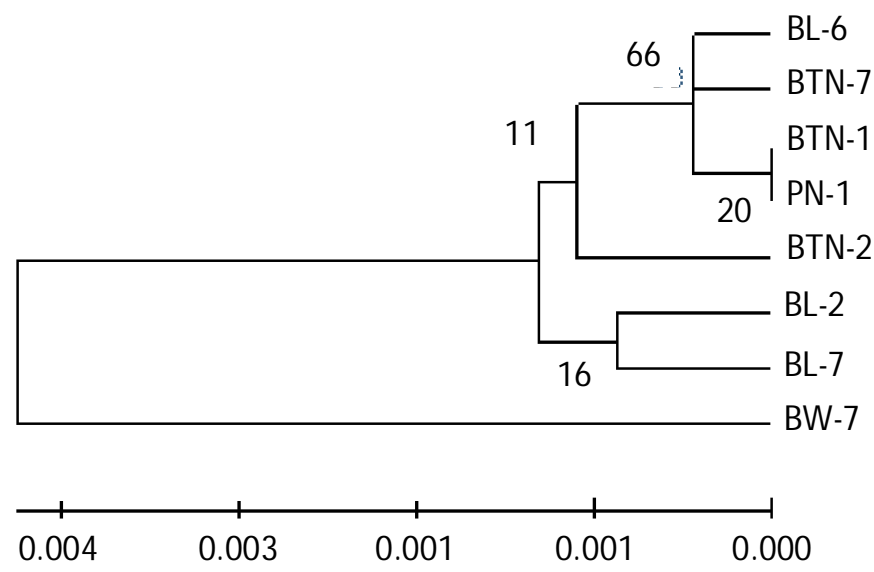

Keterangan: $\mathrm{BL}=$ Bali, $\mathrm{BTN}=$ Banten, $\mathrm{BW}=$ Banyuwangi, dan $\mathrm{PN}=$ Pangandaran

Remarks: $\quad \mathrm{BL}=$ Bali, $\mathrm{BTN}=$ Banten, $\mathrm{BW}=$ Banyuwangi, and $\mathrm{PN}=$ Pangandaran

Gambar 4. Hubungan kekerabatan antar anggota populasi Haliotis squamata dengan sebaran spasial berbeda berdasarkan jarak genetik p-distance.

Figure 4. Genetic distance between geographically different populations of Haliotis squamata based on the genetic $p$-distance.

evolusi biologi, genetik, dan tingkah laku (Livshits \& Smouse, 1993; Saunders \& Mayfield, 2008). Berdasarkan informasi yang didapatkan dari pengukuran morfometri, hanya populasi Banten yang dapat dipisahkan dengan populasi lainnya. Kurang titiktitik pengamatan spesifik pada cangkang dapat juga merupakan kelemahan dalam analisis morfometri yang dilakukan.

\section{Karakterisasi Biologi}

Persentase rasio bobot gonad terhadap bobot total tubuh paling tinggi adalah populasi Banyuwangi, Jawa
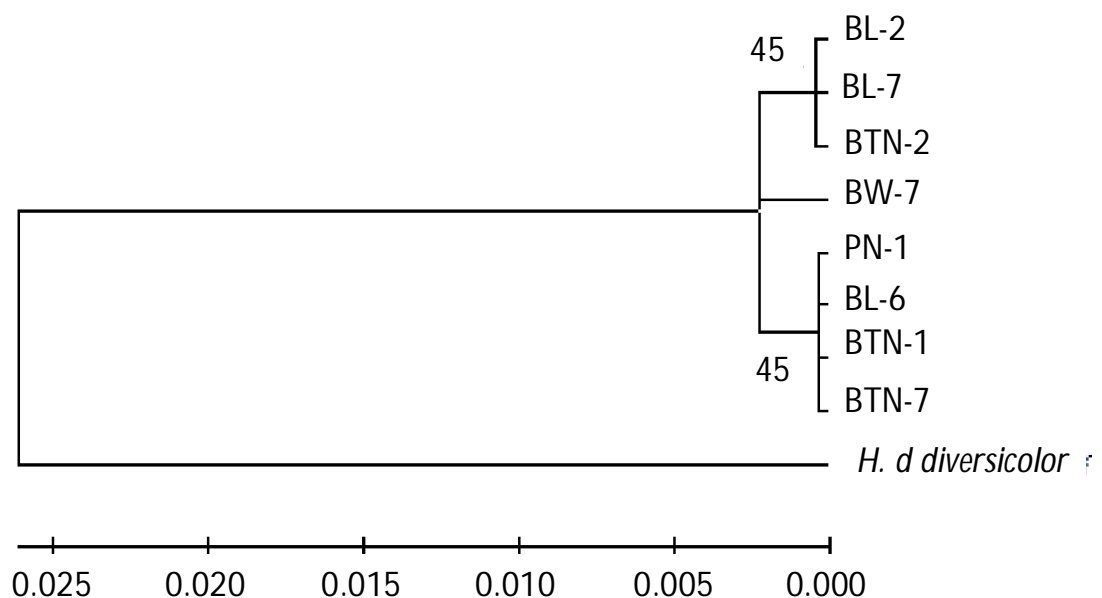

Keterangan: $\mathrm{BL}=$ Bali, $\mathrm{BTN}=$ Banten, $\mathrm{BW}=$ Banyuwangi, dan $\mathrm{PN}=$ Pangandaran Remarks: $\quad \mathrm{BL}=$ Bali, $\mathrm{BTN}=$ Banten, $\mathrm{BW}=$ Banyuwangi, and $\mathrm{PN}=$ Pangandaran

Gambar 5. Hubungan kekerabatan antar anggota populasi H. squamata dengan out-group Haliotis diversicolor diversicolor berdasarkan jarak genetik p-distance.

Figure 5. Genetic distance between populations of $\mathbf{H}$. squamata and the outgroup, H. diversicolor, based on the genetic $p$-distance. 


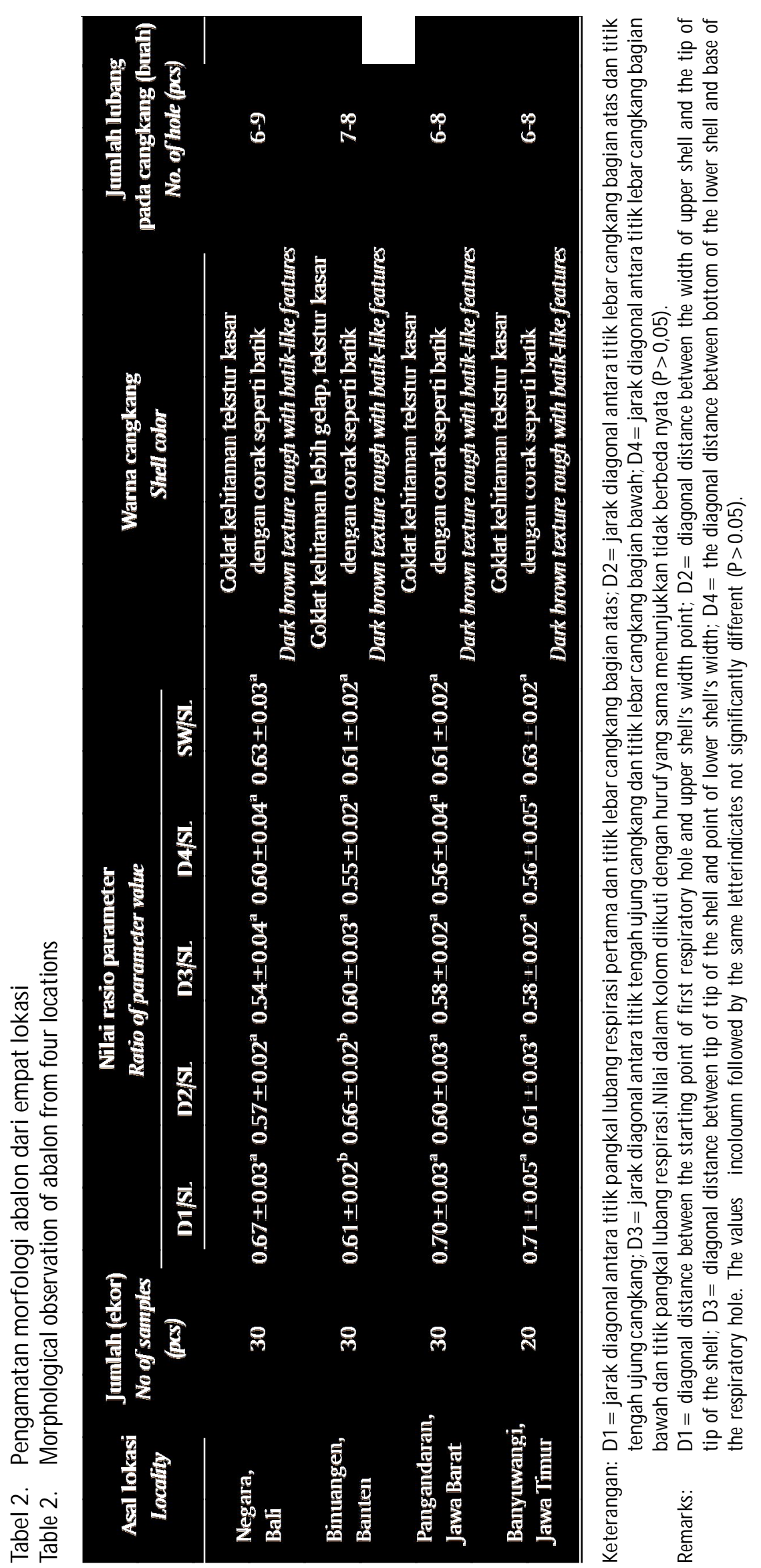




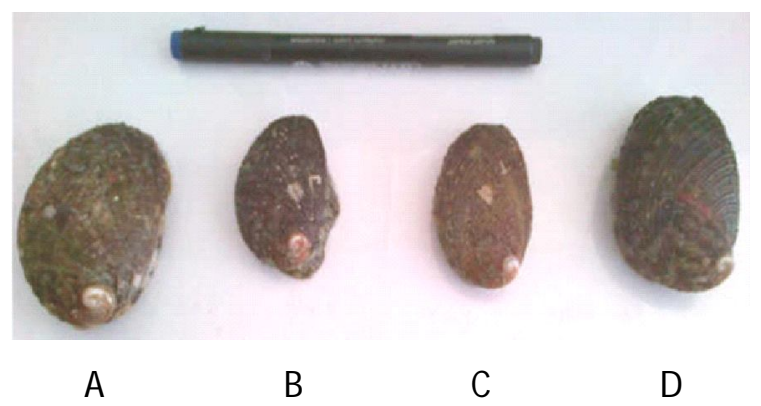

Gambar 6. Morfologi abalon H. squamata dari empat lokasi di Indonesia ( $A=$ Pangandaran, $B=$ Bali, $C=$ Banten, $D=$ Banyuwangi).

Figure 6. Morphology of abalone $\mathbf{H}$. squamata from four populations in Indonesia ( $A=$ Pangandaran, $B=$ Bali, $C=$ Banten, $D=$ Banyuwangi).

Timur, yaitu $\mathrm{m} \quad 27,9 \pm 2,39 \mathrm{~g}$ untuk jantan $(\mathrm{P}<0,05)$ dan betina sebesar $f \quad 30,1 \pm 3,02 \mathrm{~g}(P<0,05)$. Begitu juga perhitungan rasio daging (Tabel 3 ) dibandingkan dengan bobot total tubuh $(P<0,05)$. Perhitungan rasio gonad dan daging menunjukkan keunggulan populasi Banyuwangi dibandingkan dengan populasi lainnya yang diamati untuk reproduksi dan daging yang dapat dikonsumsi. Informasi tersebut sangat penting karena berhubungan dengan nilai ekonomi komoditas.

Berdasarkan data rasio gonad nampak bahwa populasi Negara, Bali yang memiliki kedekatan geografis dengan Banyuwangi, Jawa Timur menunjukkan perbedaan yang nyata $(P<0,05)$ sedangkan untuk rasio daging tidak berbeda nyata $(P>0,05)$. Data rasio gonad dan daging antara Binuangen, Banten dengan Pangandaran, Jawa Barat yang memiliki kedekatan geografis menunjukkan tidak berbeda nyata $(P>0,05)$. Hal ini dimungkinkan berhubungan dengan ketersediaan nutrisi yang berada di daerah sebaran populasi tersebut. Menurut So ewardi (2007), sebagian besar variasi fenotipe antar populasi cenderung disebabkan oleh faktor lingkungan dan sangat sedikit dipengaruhi faktor genetik. Selain itu, aspek biologi dan fisiologi makhluk hidup, efek maternal, pola makan, kompensasi pertumbuhan, dan pemeliharaan bersama (communal stocking) juga dapat memengaruhi tingkat keragaman fenotipe populasi. Tingkat kemiripan atau pheneticanalysis secara tradisional sebagai salah satu kriteria untuk menentukan jenis (McShane et al., 1988). Selain itu, informasi sejarah filogenetik merupakan penduga terbaik untuk mengetahui hal yang tidak diketahui karena morfologi, fisiologi, dan ekologi memberikan kontribusi dari penjalinan genetik suatu spesies.

Tabel 3. Pengamatan biologi abalon dari empat lokasi

Table 3. Biological observation of abalone from four populations

\begin{tabular}{|c|c|c|c|c|c|}
\hline \multirow{3}{*}{$\begin{array}{l}\text { Asal } \\
\text { Origin }\end{array}$} & \multirow{3}{*}{$\begin{array}{c}\text { Panjang } \\
\text { cangkang } \\
\text { Shell length } \\
\text { (mm) }\end{array}$} & \multicolumn{4}{|c|}{ Parameter (Parameters) } \\
\hline & & \multicolumn{2}{|c|}{$\begin{array}{l}\text { Persentase gonad terhadap bobot } \\
\text { Gonad/weight percentage (g) }\end{array}$} & \multicolumn{2}{|c|}{$\begin{array}{l}\text { Persentase daging terhadap bobot } \\
\text { Meat/weight percentage (g) }\end{array}$} \\
\hline & & $\hat{0}$ & 우 & $0^{\pi}$ & q \\
\hline Negara, Bali & $49.3 \pm 3.0$ & $21.6 \pm 2.36^{\mathrm{a}}$ & $18.3 \pm 2.03^{\mathrm{a}}$ & $61.3 \pm 4.27^{\mathrm{ab}}$ & $68.5 \pm 5.99^{\mathrm{a}}$ \\
\hline Banyuwangi, Jawa Timur & $56.1 \pm 6.2$ & $27.9 \pm 2.39^{b}$ & $30.1 \pm 3.02^{b}$ & $67.8 \pm 2.61^{\mathrm{a}}$ & $69.5 \pm 3.73^{\mathrm{a}}$ \\
\hline Binuangen, Banten & $51.1 \pm 5.5$ & $14.6 \pm 2.24^{c}$ & $17.5 \pm 4.69^{\mathrm{a}}$ & $58.7 \pm 3.13^{a b}$ & $59.6 \pm 5.65^{b}$ \\
\hline Pangandaran, Jawa Barat & $61.9 \pm 6.9$ & $19.6 \pm 1.91^{\mathrm{a}}$ & $18.1 \pm 3.33^{\mathrm{a}}$ & $62.1 \pm 3.74^{\mathrm{ab}}$ & $58.9 \pm 2.29^{b}$ \\
\hline
\end{tabular}

Keterangan: Nilai dalam baris diikuti dengan huruf yang sama menunjukkan tidak berbeda nyata $(P>0,05)$

Remarks: The values in the same row followed by the same letter indicates no significant difference $(P>0.05)$ 


\section{KESIMPULAN}

Morfometrik cangkang berbeda pada populasi Banten dengan indikasi adanya pertumbuhan asimetri. Rasio gonad nampak bahwa populasi Negara, Bali yang memiliki kedekatan geografis dengan Banyuwangi, Jawa Timur menunjukkan perbedaan yang nyata $(P<0,05)$ sedangkan untuk rasio daging tidak berbeda nyata $(P>0,05)$. Data rasio gonad dan daging antara Binuangen, Banten dengan Pangandaran, Jawa Barat yang memiliki kedekatan geografis tidak berbeda nyata $(P>0,05)$. Keragaman inter populasi $H$. squamata telah menunjukkan adanya tujuh haplotipe namun terdiri dua kelompok besar di mana Banyuwangi terpisah dari kelompok lainnya. Di antara kelompok populasi $H$. squamata dengan sebaran spasial berasal dari Bali dan Banten memiliki ragam haplotipe sama-sama beragam. Jarak genetik antara $\mathrm{H}$. squamata dan $\mathrm{H}$. diversicolor diversicolor adalah sebesar 5,2\%

\section{UCAPAN TERIMA KASIH}

Penelitian ini dilaksanakan atas dana Anggaran Pendapatan dan Belanja Negara (APBN) 2014. Penulis mengucapkan terima kasih kepada seluruh staf teknisi bioteknologi dan teknisi abalon atas segala bantuan selama penelitian ini.

\section{DAFTAR ACUAN}

An, H.S., Jee, Y.J., Min, K.S., Kim, B.L., \& Han, S.J. (2005). Phylogenetic analysis of six species of pacific abalone (Haliotidae) based on DNA sequences of 16s rRNA and cytochrome c oxidase subunit I mitochondrial genes. Mar. Biotechnol., 7(4), 373-380.

Brown, W.M., George, M.Jr., \& Wilson, A.C. (1979). Rapid evolution of animal mitochondrial DNA 76 (pp 1967-1971). USA: Proc. Natl. Acad. Sei.

Dharma, B. (2008). Moluska unggulan Indonesia sebagai sumber pangan. Makalah dipresentasikan pada Seminar M oluska II, penyelenggara IPB. Bogor, $16 \mathrm{hlm}$.

Fahruddin, Permana, G.N., \& Haryanti. (2010). Evaluasi keragaman genetik induk Abalon (Haliotis squamata) dan benih. Prosiding Forum Inovasi Teknologi Akuakultur (FITA). hlm. 485-481.

Klinbunga, S., Pripue P., Khamnamtong, N., Puanglarp, N., Tassanakajon, A., Jarayabhand, P., Hirono, I.,
Aoki, T., \& Menasveta, P. (2003). Genetic diversity and molecular markers of the tropical abaIone (Haliotis asinina) in Thailand. Marine Biotechnology, 5(5), 505-517.

Livshits, G. \& Smouse, P.E. (1993). Relation between fluctuating asymmetry, morphological maodality and heterozygosity in an elderly iraeli population. Genetica, 89, 155-166.

Møller, A.P. \& Swaddle, J.P. (2002). Asymmetry, developmental stability and evolution. Oxford Series in Ecology and Evolution. Oxford University Press, $292 \mathrm{pp}$.

McShane, P.E., Smith, M.G., \& Beinssen, K.H.H. (1988). Growth and morphometry in abalone (Haliotis rubra leach) from Victoria. Aust. J. Mar. Freshw. Res., 39, 161-166.

Priyambodo, B., Sofyan, Y., \& Jaya, I.B.M.S. (2005). Produksi benih tiram abalon (Haliotis asinine) di Loka Budidaya Laut Lombok. Prosiding Seminar Nasional Tahunan Hasil Penelitian Perikanan dan Kelautan.UGM. Jogjakarta, $5 \mathrm{hlm}$.

Saunders, T. \& Mayfield, S. (2008). Predicting biological variation using a simple morphometric marker in the sedentary marine invertebrate predicting biological variation using a simple morphometric marker in the sedentary marine invertebrate Haliotis rubra. Mar. Ecol. Prog. Ser., 366, 75-89.

Saunders, T.M., Connell, S.D., \& Mayfield, S. (2009). Differences in abalone growth and morphology between locations with high and low food availability: morphologically fixed or plastic traits?. Marine Biology International Journal on Life in Oceans and Coastal Waters, 156(6), 1255-1263.

Soelistyowati, D.T., Kusumawardhahi, A., \& Zairin, J.M. (2013). Karakterisasi fenotipe benih hybrida interspesifik abalon, Haliotis asinina dan Haliotis squamata. Jurnal Akuakultur Indonesia, 12(1), 2632.

Soewardi, K. (2007). Pengelolaan keragaman genetik sumberdaya perikanan dan kelautan. Departemen Manajemen Sumberdaya Perairan, Institut Pertanian Bogor. Bogor, $153 \mathrm{hlm}$.

Tomura, K., Duddley, J., Nei, M., \& Kumar, S. (2011). Mega 5: Molecular Evolutionary Genetics Analysis (MEGA) sofware version 5.0. J. Mol. Biol. Evol., 24, 1596-1599. 